\title{
Sweet orange scab with a new scab disease "syndrome" of citrus in the USA associated with Elsinoë australis
}

\author{
Madhurababu Kunta ${ }^{1}$, John Rascoe ${ }^{2}$, Patricia B. de Sa $^{2}$, Lavern W. Timmer ${ }^{3}$, Mary E. Palm² ${ }^{2}$ John V. da Graça', \\ Robert L. Mangan ${ }^{4}$, Nasir S.A. Malik ${ }^{4}$, Bacilio Salas ${ }^{5}$, Aditi Satpute ${ }^{1}$, Mamoudou Sétamou$^{1}$ \& Mani Skaria ${ }^{1}$ \\ ${ }^{1}$ Texas A\&M University-Kingsville, Citrus Center, 312 North International Blvd, Weslaco, TX 78596; ${ }^{2}$ USDA-APHIS-PPQ, Bldg. \\ 580, BARC-East, Powder Mill Road, Beltsville, MD 20705; ${ }^{3}$ University of Florida, Citrus Research \& Education Center, 700 \\ Experiment Station Rd, Lake Alfred, FL 33850; ${ }^{4}$ USDA-ARS, 2413 East Highway 83, Bldg. 201, Weslaco, TX 78596; ${ }^{5}$ USDA- \\ APHIS-PPQ-CPHST, 22675 N Moorefield Rd, Edinburg, TX 78541
}

Author for correspondence: Madhurababu Kunta, e-mail: madhura.kunta@tamuk.edu

\begin{abstract}
Elsinoë fawcettii causes citrus scab and E. australis causes sweet orange scab and there are different pathotypes of each species. Citrus scab is widely distributed, whereas sweet orange scab is limited mostly to southern South America. In 2010, E. australis was detected by PCR in Texas for the first time in the USA and subsequently found in commercial areas of Texas. In this study, cultures were obtained in Texas mostly from diseased fruit with symptoms similar to "late-season windscar" and identified as the Natsudaidai pathotype of $E$. australis by sequencing of the PCR amplification products and sequencing of the translation elongation factor and ITS regions. Inoculations of detached leaves and fruit of grapefruit, sweet orange, and tangerine produced scab-like symptoms on all organs and species. The fungus was re-isolated from the inoculated organs and PCR tests on re-isolated fungal colonies and lesions confirmed the presence of E. australis. The disease represents sweet orange scab of citrus with a new scab disease symptomatology, but the host range, ecology and epidemiology of this pathotype are still not completely understood. Thus far, Natsudaidai pathotype has been reported only from South Korea.
\end{abstract}

Key words: Citrus paradisi, Citrus reticulata, Citrus sinensis, Elsinoë australis, Elsinoë fawcettii, ITS region.

\section{INTRODUCTION}

Two scab diseases on citrus are common commercial problems in many humid citrus areas: citrus scab, caused by Elsinoë fawcettii, and sweet orange scab (SOS), caused by E. australis (Chung, 2010; Whiteside, 1975). Citrus scab (syn. Sour orange scab) was recorded in the Gulf Coast region of East Texas before 1923, and was confirmed to be present in the Lower Rio Grande Valley (LRGV) in 1973 (Timmer, 1974). Elsinoë fawcettii has many pathotypes (Timmer et al., 1996) that vary considerably in the hosts they attack, but fruit and leaves of many tangerines (Citrus reticulata) and their hybrids, grapefruit (C. paradisi), lemons (C. limon) and other citrus species are affected. This species only rarely affects sweet orange fruit, but never attacks leaves of sweet orange (C. sinensis). Only the Florida broad host range (FBHR) pathotype of E. fawcettii is occasionally found on sweet orange (Timmer, 1974; Whiteside, 1975). Citrus scab is cosmopolitan in its distribution. Sweet orange scab is less well-studied, but generally affects only fruit of sweet orange

Current address for Mary E. Palm: USDA/APHIS/PPQ/PHP/QPAS, National Identification Services, 4700 River Rd., Riverdale Maryland 20737. and mandarins (C. reticulata) and their hybrids (Jenkins, 1933). It is generally confined to southern South America and has never been reported in the USA (Timmer, 1974). Hyun et al. (2001) recovered another pathotype of $E$. australis from a single tree of $C$. natsudaidai in South Korea and termed the South American strains as the Sweet Orange pathotype and the Korean strain as the Natsudaidai pathotype. None of the known pathotypes of sweet orange scab affects leaves. Both pathotypes of E. australis and some pathotypes or groups of pathotypes of E. fawcettii can be distinguished using specific DNA primers (Hyun et al., 2007).

Immature young fruit up to 6 to 8 weeks after petal fall are highly vulnerable to citrus scab (Whiteside, 1975). The fungus survives and spreads through the production of conidia on the fruit surface (Whiteside, 1975). Conidia are fragile and short-lived, but need only 2 to $3 \mathrm{~h}$ of continuous moisture to germinate and infect citrus tissues (Agostini et al., 2003; CABI, 2010).

In this paper, we report the first detection of the fungus in the USA, isolation and culture of the pathogen, inoculation of detached citrus leaves and fruit, re-isolation of the fungus, and confirmation of the identity through symptoms, fungal morphology, and PCR. We sequenced the partial translation elongation factor (TEF) and the internal transcribed spacer (ITS) and compared the sequences with those of isolates of E. australis and E. fawcettii. 


\section{MATERIALS AND METHODS}

\section{Fungal morphology and pathogenicity tests}

\section{Fungal isolation}

Symptomatic fruit and leaves were collected from citrus orchards in the Lower Rio Grande Valley in Texas in 2010. The fruit was then washed under running water for $10 \mathrm{~min}$, soaked in sterile distilled water (SDW) containing a few drops of Dawn dishwashing detergent (Procter \& Gamble) in a beaker for $20 \mathrm{~min}$, rubbed clean with a sponge under running water, air dried for $30 \mathrm{~min}$, soaked in SDW containing 2-5\% Chlorox (5.95\% sodium hypochlorite) for 5-10 min, rinsed with SDW several times, and left on paper towels placed on a workbench for 2-3 days. The fruit were swabbed with $95 \%$ ethanol, dried in a laminar flow hood, and scab pustules were scraped using a sharp scalpel to deposit tiny flakes onto the surface of the Whiteside's semi-selective medium (Whiteside, 1975). The plates were kept on a workbench in the laboratory at $25^{\circ} \mathrm{C}$ and observed daily for fungal growth. After 7-10 days, the slow-growing colonies were transferred to antibiotic-amended potato dextrose agar (PDA) (39 g PDA, $0.1 \mathrm{~g}$ tetracycline, and $0.1 \mathrm{~g}$ streptomycin per liter of water). Once pure cultures of the fungus were successfully established on antibiotic-amended PDA, stock cultures were established on PDA and maintained by transferring to new plates every 30-45 days to maintain viability of the fungus.

\section{Conidial production}

For inoculation assays, conidia were produced using procedures described by Timmer (1974) with minor modifications. Briefly, colonies from isolates SOS-035 and SOS-200 (Table 1) were grown on PDA with no antibiotics for 7 to 10 days. Small pieces of actively growing mycelium without agar were removed from the PDA and placed on the bottom of a petri dish, crushed with a spatula into minute fragments, and then 5 to 6 $\mathrm{mL}$ of liquid Fries medium was poured into the plate and stirred to dislodge the fragments from the petri dish. The plates were incubated for $48 \mathrm{~h}$ at $25-27^{\circ} \mathrm{C}$ and observed under a stereomicroscope to check for the growth of microcolonies on the bottom of the plates. The microcolonies were washed three times by pouring SDW into the plates, leaving for 10-20 min, swirling the plates to make sure all the nutrients were dissolved in the water, and then carefully pouring water from the plate. Autoclaved pond water was then added to the plates until the microcolonies were barely covered. The petri dishes were incubated overnight in the dark at $25-27^{\circ} \mathrm{C}$. The pond water was poured from the plate, the conidia were dislodged using a camelhair brush, SDW was added to the plate and the plate was shaken vigorously. For inoculations, the conidial concentration was adjusted to $1 \times 10^{5} \mathrm{~mL}^{-1}$ using a haemocytometer.
Inoculation of detached immature young leaves and fruit

Three young leaves $(1 / 3-1 / 2$ expanded) per cultivar were collected from grapefruit, sweet orange, lemon and tangerine. In two separate leaf inoculation experiments for each isolate, two leaves were inoculated with spore suspensions from SOS 035 or SOS 200 (Table 1) and one leaf with SDW remained as a control. The inoculation experiments were repeated three times. The leaves were disinfected by placing them for $2 \mathrm{~min}$ in $0.5 \%$ Chlorox, dipping in 50\% ethanol for $2 \mathrm{~min}$ each, rinsing in SDW several times. The leaves were blot-dried on sterile paper towels and placed either on water agar $(1.5 \%)$ or sterile moist filter paper in petri plates. Five $\mu \mathrm{L}$ of the conidial suspension was placed on the abaxial side of the leaf; the plates were sealed with parafilm, and incubated in a humid chamber at 25 to $27^{\circ} \mathrm{C}$ in the dark.

Three small, immature (3- to 8-week-old) citrus fruit for each species with the pedicel attached were collected from grapefruit, tangerine, and sweet orange trees. A small leaf was kept on the surface of the fruit, and wrapped with moist cotton. From the stylar end, $10 \mu \mathrm{L}$ of spore suspension derived from SOS 200 (Table 1) was poured between the leaf and fruit; the fruit was placed in a closed humid chamber and observed for the symptom development. Control fruit were treated similarly with SDW. The inoculation experiments were repeated twice.

\section{Molecular diagnosis and characterization}

\section{DNA extraction}

Fruit and leaf material showing typical scab symptoms (Figure 1) were collected from several places in Texas including citrus orchards, nurseries, dooryard trees, and retail grocery stores (Table 1) as part of an ongoing citrus commodity survey. The scab pustules were scraped from fruit (avoiding flavedo tissue) and from leaf samples using a sharp razor blade, collected in a $2 \mathrm{~mL}$ Lysing Matrix A tube (MP Biomedicals, LLC., Solon, $\mathrm{OH}$ ) and the tissue was disrupted in a Mini-Beadbeater-96 (Biospec Products, Bartlesville, OK). The total genomic DNA was isolated using Qiagen DNeasy Plant Mini Kit (Qiagen Inc., Valencia, CA) following manufacturer's instructions and the DNA was stored at $-20^{\circ} \mathrm{C}$ until used.

\section{Diagnostic PCR}

Two $\mu \mathrm{L}$ of DNA was used as a template in the diagnostic PCR tests consisting of $25-\mu$ L reaction mixture with $2.5 \mu \mathrm{L}$ 10X PCR buffer (Invitrogen, Carlsbad, CA), $2.5 \mathrm{mM} \mathrm{MgCl}_{2}, 0.2 \mathrm{mM}$ each dNTPs, $0.2 \mu \mathrm{M}$ each primers, and 1 Unit platinum Taq DNA polymerase (Invitrogen). The primer pairs Efaw-1 and Efaw-2, and Eaut-1 and Eaut-5 were used to specifically detect E. fawcettii and $E$. australis, respectively, and the PCR conditions were the same as described by Hyun et al. (2007). All further confirmative PCR tests to detect E. australis were done using the Eaut-5 primer pair. NS1/NS2 primers (Dams 
TABLE 1 - The Elsinoë isolates used in the production of Neighbor-joining consensus tree based on internal transcribed spacer region and translation elongation factor $1 \alpha$ gene. The isolates marked with $\left(^{*}\right)$ were isolated by the authors and the remainder are from the GenBank database that showed nucleotide sequence similarity to sequences from several E. australis isolates in this study

\begin{tabular}{|c|c|c|c|}
\hline Geographical origin & Host plant & Isolate No. & GenBank accession numbers \\
\hline Weslaco, TX, USA* & Marrs sweet orange & SOS 002 & KC211034 \\
\hline Weslaco, $\mathrm{TX}^{*}$ & Marrs sweet orange & SOS 012 & $\mathrm{KC} 211035$ \\
\hline Mission, $\mathrm{TX}^{*}$ & Sweet orange & SOS 019 & $\mathrm{KC} 211036$ \\
\hline Mission, $\mathrm{TX}^{*}$ & Sweet orange & SOS 031 & KC211037 \\
\hline Mission, TX* & Sweet orange & SOS 035 & - \\
\hline Mission, $\mathrm{TX}^{*}$ & Rio Red grapefruit & SOS 040 & $\mathrm{KC} 211038, \mathrm{KC} 211048$ \\
\hline Mission, $\mathrm{TX}^{*}$ & Rio Red grapefruit & SOS 047 & $\mathrm{KC} 211039, \mathrm{KC} 211050$ \\
\hline Mission, $\mathrm{TX}^{*}$ & Sweet orange & SOS 054 & $\mathrm{KC} 211040, \mathrm{KC} 211051$ \\
\hline Mission, $\mathrm{TX}^{*}$ & Sweet orange & SOS L54 & $\mathrm{KC} 211041, \mathrm{KC} 211049$ \\
\hline Mission, $\mathrm{TX}^{*}$ & Tangerine & SOS 061 & $\mathrm{KC} 211033, \mathrm{KC} 211047$ \\
\hline Weslaco, TX* & Sweet orange & SOS 138 & - \\
\hline Mission, $\mathrm{TX}^{*}$ & Sweet orange & SOS 200 & - \\
\hline Austin, $\mathrm{TX}^{*}$ & Rio Red grapefruit & SOS 225 & - \\
\hline South Korea (Jeju Island) & Yuzu (C. junos $)$ & Yuzu 1-3 & FJ010285 \\
\hline São Paulo, Brazil & Murcott tangor & VRG-7L-5 & FJ010283 \\
\hline Florida & Temple tangor & Smoak-1 & FJ010280 \\
\hline South Korea (Jeju Island) & Satsuma mandarin & SM24-4 & FJ010279 \\
\hline New Zealand & Yen Ben lemon & 70298 & FJ010216 \\
\hline Florida & Murcott & MUR-3 & FJ010240 \\
\hline São Paulo & Sweet orange & VRG-BRT & FJ010284 \\
\hline São Paulo & Sweet orange & FZ-STM-CL & FJ010242 \\
\hline Argentina & Satsuma mandarin & $\mathrm{Ea}-4$ & FJ010239 \\
\hline Argentina & Satsuma mandarin & Ea-3 & FJ010238 \\
\hline South Korea (Jeju Island) & Natsudaidai & $\mathrm{KNa}-1$ & FJ010250 \\
\hline South Korea (Jeju Island) & Natsudaidai & $\mathrm{KNa}-2$ & FJ010251 \\
\hline South Korea (Jeju Island) & Natsudaidai & $\mathrm{KNa}-5$ & FJ010252 \\
\hline South Korea (Jeju Island) & Natsudaidai & $\mathrm{KNa}-9$ & FJ010253 \\
\hline South Korea (Jeju Island) & Natsudaidai & $\mathrm{Na}-1$ & FJ010259 \\
\hline Hidalgo County, TX* & Sweet orange & S5174A & $\mathrm{KC} 211042, \mathrm{KC} 211053$ \\
\hline McAllen, TX* & Sweet orange & S5174B & KC211052 \\
\hline McAllen, TX* & Grapefruit & S5077B & $\mathrm{KC} 211043, \mathrm{KC} 211054$ \\
\hline McAllen, TX* & Grapefruit & S5074A3 & $\mathrm{KC} 211044, \mathrm{KC} 211055$ \\
\hline McAllen, TX* & Grapefruit & S5074A1 & $\mathrm{KC} 211045, \mathrm{KC} 211056$ \\
\hline Spring, TX* & Citrus spp. & S3829C & $\mathrm{KC} 211046$ \\
\hline USA & Unknown & AFTOL-ID.1360 & QQ677902 \\
\hline USA & Unknown & AFTOL-ID.1853 & DQ767641 \\
\hline South Korea (Jeju Island) & Satsuma mandarin & SM3-1 & FJ010360 \\
\hline South Korea (Jeju Island) & Yuzu & YuZu2-2 & FJ010357 \\
\hline South Korea (Jeju Island) & Yuzu & Yuzu2 -1 & FJ010356 \\
\hline South Korea (Jeju Island) & Kinkoji (C. obovoidea) & Maru-2 & FJ010331 \\
\hline South Korea (Jeju Island) & Satsuma mandarin & SM16-4 & FJ010346 \\
\hline South Korea (Jeju Island) & Natsudaidai & $\mathrm{Na}-2$ & FJ010336 \\
\hline Australia & $\begin{array}{l}\text { Jojoba (Simmondsia } \\
\text { chinensis) }\end{array}$ & Ea-J02 & GU126378 \\
\hline Australia & Jojoba & DAR77387 & GU126376 \\
\hline Argentina & Satsuma mandarin & Ea-1 & FJ010312 \\
\hline Argentina & Valencia sweet orange & 70041 & FJ010289 \\
\hline Argentina & Satsuma mandarin & 70212 & FJ010291 \\
\hline
\end{tabular}

et al., 1988; Glass \& Donaldson, 1995) were used as internal controls to confirm presence of amplifiable DNA in the extract. Furthermore, EaNat-1 primers were used to test for the Natsudaidai pathotype. PCR amplification products were separated by electrophoresis on $1 \%$ agarose gels, ethidium-bromide stained, visualized under UV light, and photographed using Biospectrum imaging system (UVP, Upland, CA).

\section{PCR for sequence characterization of TEF and ITS regions} DNA was isolated from fungal cultures (Table 1) using a Qiagen kit as previously described. PCR reactions 

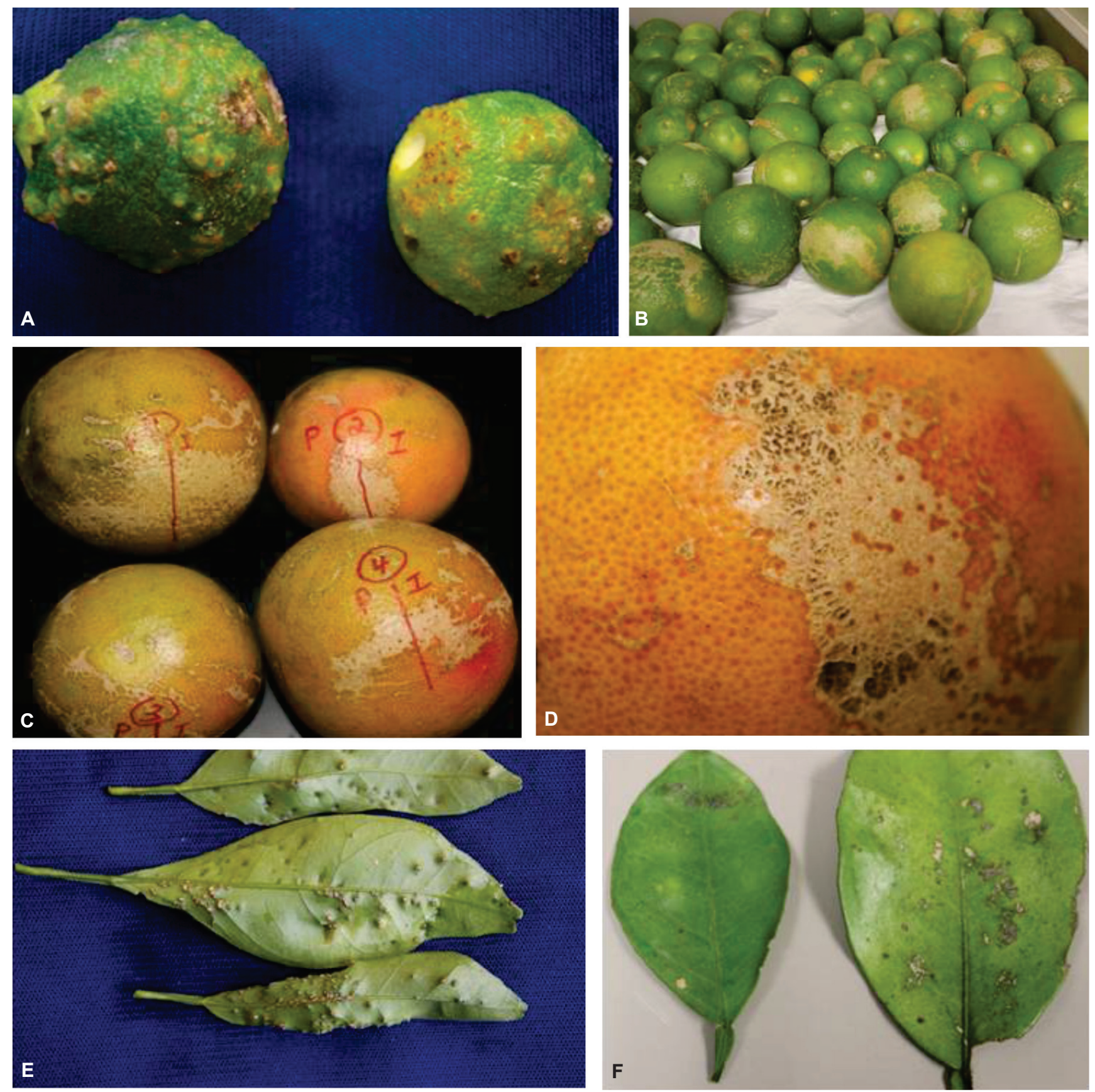

FIGURE 1 - Field symptoms of sweet orange scab with a new scab disease symptomatology associated with Elsinoë australis on citrus fruit on A. satsuma mandarin; B. sweet orange; C. grapefruit; D. a close-up of grapefruit "late season windscar" symptom and on leaves of E. satsuma mandarin; F. sweet orange.

were performed using $12.5 \mu \mathrm{L}$ Takara Ex Taq master mix (Clonetech Laboratories Inc., Mountain View, CA), 0.5 $\mu \mathrm{L}$ each primer $(10 \mu \mathrm{M}), 9.5 \mu \mathrm{L}$ water, and $2 \mu \mathrm{L}$ DNA. TEF runs using primers elongation-1-F and elongation-1-R (Hyun et al., 2009) consisted of $95^{\circ} \mathrm{C}$ for $120 \mathrm{sec}, 35$ cycles of $94^{\circ} \mathrm{C}$ for $30 \mathrm{sec}, 60^{\circ} \mathrm{C}$ for $60 \mathrm{sec}, 72^{\circ} \mathrm{C}$ for $120 \mathrm{sec}$, followed by $10-\mathrm{min}$ extension at $72^{\circ} \mathrm{C}$. A longer portion of the region spanning ITS1-ITS2 was reproduced from culture samples using the primer pair Elsi.24F/ITS4. PCR products were sequenced directly at MCLAB (MCLAB,
San Francisco, CA) and analyzed using Geneious Pro 5.4.4 software (Drummond et al., 2011). Forward and reverse sequences were aligned and edited and multiple alignments were carried out with Geneious Alignment. Neighborjoining phylogenetic trees were estimated with Geneious Tree Builder using the Tamura-Nei genetic distance model, and replicated with bootstrapping (1,000 replications).

The PCR amplification products were excised from the gels and extracted using the Qiaquick gel extraction kit (Qiagen). Purified DNA fragments were ligated into 
pCR4-TOPO cloning vector and transformed into DH5 $\alpha-$ T1R one-shot chemically competent Escherichia coli cells using the TOPO TA cloning kit for sequencing (Invitrogen). Further plasmid DNA extractions were carried out using QIAprep spin miniprep kit (Qiagen) and the purified DNA was sequenced at the Iowa State University DNA sequencing facility. Sequences were edited and analyzed using Geneious Pro 5.4.4 and homology searches were conducted using BLASTn program in GenBank (www. ncbi.nlm.nih.gov).

\section{RESULTS}

\section{Symptoms observed, disease occurrence and background}

In July 2010, a lemon fruit collected with scab-like symptoms from a residential area in Spring, TX (a Houston suburb) as part of an ongoing citrus commodity survey gave a positive PCR result for E. australis. The fruit had small, flat lesions similar to scab on lemons caused by species of Elsinoë. Later, Satsuma mandarin (C. unshiu) fruit collected from East Texas also produced a PCRpositive test result for $E$. australis. These fruit had more prominent and extensive scab-like lesions that were not typical of SOS symptoms described from other countries. Additional samples collected in East Texas by the United States Department of Agriculture - Animal and Plant Health Inspection Service - Plant Protection and Quarantine (USDA-APHIS-PPQ) were found to be positive for E. australis using specific DNA primers and sequence analysis of the PCR products (Hyun et al., 2007). Elsinoë australis was isolated in pure culture from samples received by the PPQ. On August 23, 2010, USDA-APHIS announced the presence of $E$. australis in residential properties in Harris and Orange counties in Texas and Orleans parish in Louisiana.

Later, several grapefruit and sweet orange samples collected in the LRGV of Texas were also positive for E. australis in molecular diagnostic assays and it was detected on samples from Mississippi and Florida in October and December of 2010, respectively. The fungus was identified by PCR in several counties in Florida and was detected in Arizona in January, 2011. Many of the fruit and leaves assayed had lesions similar to those expected of a scab disease. However, many positive PCR reactions were from a wide range of symptoms including those associated with windscar, thorn punctures, bird damage and various types of damage to leaves and fruit.

Symptoms in the field were variable. In the Lower Rio Grande Valley of Texas, PCR positive results were obtained primarily from a symptom usually referred to by growers as "late-season windscar" (J. W. Sauls, personal communication). However, symptoms on fruit ranged from small, flattened off-white pustules to large coalesced lesions (Figure 1 A, B, C, D). The leaf lesions were relatively large and coalesced on the margins of the upper side of the leaf (Figure 1E, F). The aforementioned symptoms are in contrast to those reported by Bitancourt
\& Jenkins (1937) and Jenkins (1933) in South America as small lesions on the lower side of the sweet orange leaf, mostly on midrib. The PCR positive samples for $E$. australis that were sent to PPQ from various locations varied in size, shape and color. On some leaves, small raised rust-to-brown, rounded scabs were seen on the lower side of the leaves. On tangerine, lemon, and grapefruit, small, elongated rust-colored lesions on underside and upper side of leaves were observed. On several citrus species including tangerines, grapefruit, other non-specified citrus and Fortunella sp., foliar lesions were large, broad, coalesced and somewhat crustlike, rust-colored and darker brown or black lesions extending along the margins on the underside of leaves. Sweet orange and other unidentified citrus showed small lesions dispersed through the leaf blade on the lower and upper side of the leaves. On fruit of grapefruit, satsumas and tangerines, circular or elongated, depressed areas of the peel were surrounded by scabby cream- to rust-colored tissue with puckering of the green part of the peel around the lesion, alternatively the entire lesion was covered in scabby tissue. Scabby cream-to-brown lesions were seen surrounding the petiole of some fruit, particularly grapefruit. On other fruit, scabby lesions were dispersed, as if spread by water splash or scratches, and were in some cases crusty and brown to dark brown and slight raised. Microscopic examination, isolations on selective media (Whiteside, 1975) and PCR amplifications indicated that on some samples, there were several fungi growing on some lesions on fruit and leaves, resulting in a certain variation in symptoms making it difficult to relate the symptoms exclusively to the presence of E. australis.

The USDA-APHIS established a technical working group with researchers and authorities from universities and regulatory agencies to develop survey and disease mitigation strategies. In December, 2010, SOS quarantine areas were established for Texas, Mississippi and Louisiana and conditions were outlined that must be met to allow interstate movement of fruit to protect citrus-producing states and trading partners. Equivalent measures were also imposed on fresh fruit imports, as several shipments of Tahiti lime (C. latifolia) were positive for E. australis by PCR. Later, in March, 2011, APHIS revised the federal order to include Florida and Arizona in the quarantine areas. APHIS has also established guidelines for use of approved fungicides in plant nurseries and packinghouse procedures to be followed to allow interstate movement of fruit.

\section{Fungal colony and conidial characteristics}

Colonies resembling Elsinoe spp. were obtained in pure culture from more than 25 fruit samples. Colonies were slow-growing, beige, pink, orange, orange-beige, to purplish beige, about $17 \mathrm{~mm}$ in diameter in 30 days, very irregularly shaped with a wrinkled, cerebriform surface which resembled callus tissue (Figure 2). The conidia 
produced were hyaline, ovoid and typical of those described for E. australis (CABI, 2010; Timmer, 1974). The fungal cultures are available at TAMUK Citrus Center, Weslaco, TX and USDA-APHIS, Edinburg, TX.

\section{Detached leaf and fruit inoculation}

Detached leaf assays showed scab symptoms 5 to 7 days after inoculation and sweet orange, grapefruit and lemon were highly susceptible (Figure 3). Fruit of grapefruit, tangerine, and sweet orange inoculated with E. australis isolates developed scab symptoms 8 to 10 days after inoculation (Figure 4). The fungus was successfully re-isolated from the inoculated leaf and fruit tissue by the methods described above. Furthermore, the PCR tests on DNA isolated directly from the lesion on the inoculated tissue and also on DNA isolated from the re-isolated fungal colonies confirmed the presence of $E$. australis.

\section{Molecular characterization}

PCR amplifications using DNA isolated from citrus scab lesions as a template and E. fawcettii-specific primers, Efaw-1 and Efaw-2, produced PCR amplicons of two sizes: $717 \mathrm{bp}$ and $334 \mathrm{bp}$ (not shown). Homology searches in GenBank indicated $100 \%$ identity with an E-value of 1e-173 to previously deposited E. fawcettii sequences. PCR amplifications using the two primer sets Eaut- 1 and Eaut-5 on new scab disease lesions including "late season wind scar" resulted in two amplification products of $548 \mathrm{bp}$ (not shown) and $363 \mathrm{bp}$ (Figure 5), respectively, with $100 \%$ identity to E. australis in GenBank homology searches. Amplifications using
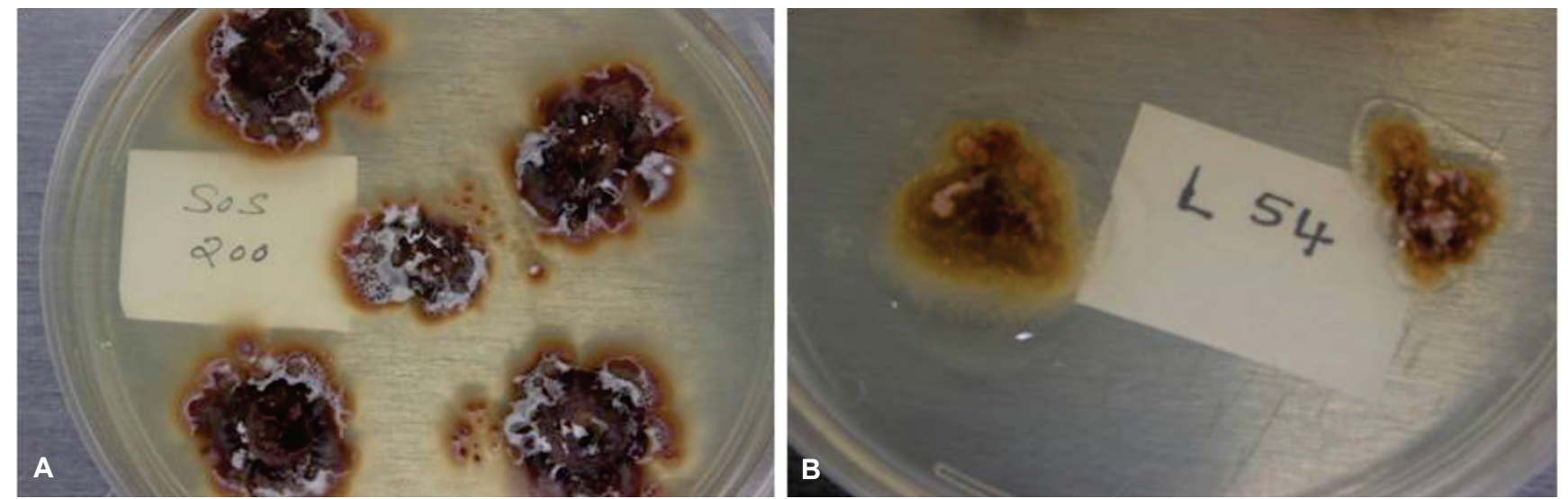

FIGURE 2 - Elsinoë australis isolates obtained in pure culture showing very irregular shape with a wrinkled, cerebriform surface resembling callus tissue. $a$
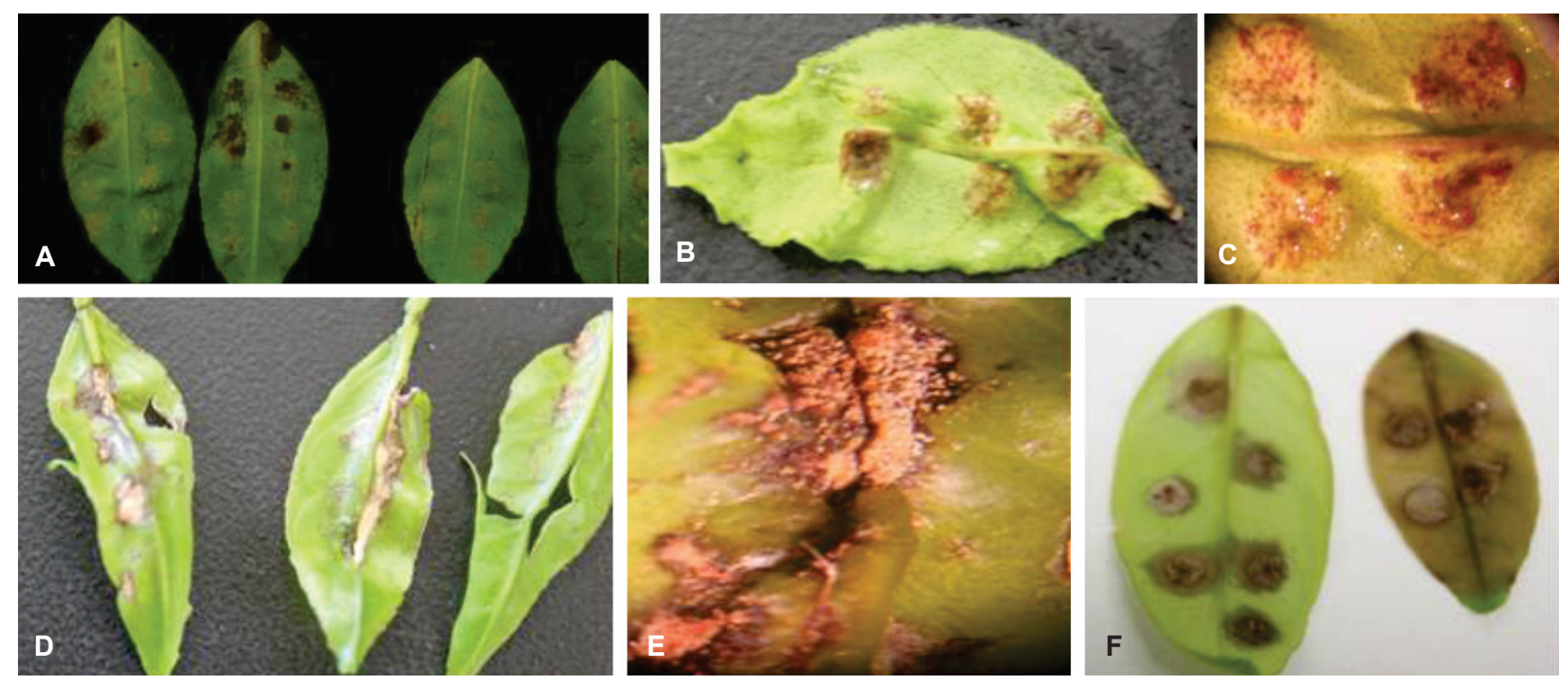

FIGURE 3 - Young citrus leaves developed scabby lesions 7 days after inoculation with conidial suspensions. A. Rio Red grapefruit; B. mandarin; C. a close-up of mandarin lesion; D. Pineapple sweet orange; E. a close-up of sweet orange lesion and F. lemon. 
EaNat1 primers targeting the Natsudaidai pathotype resulted in 578-bp PCR amplicons as expected (Figure 5). The Satsuma mandarin leaf sample collected from East Texas and sweet orange leaf collected from Mission, Texas (Figure 1) gave a positive PCR test result using Eaut-5 primers for E. australis. These are the only leaf samples in the Lower Rio Grande Valley from which we ever detected the fungus and no cultures have been obtained from symptomatic leaves. Some of the initial test results in detecting $E$. australis were confirmed by USDA-APHIS-PPQ molecular diagnostic laboratory in Beltsville, MD.

The sequence analysis further confirmed the identity of these isolates as E. australis. Neighbor-joining (NJ) analysis of the TEF resulted in three clades, each corresponding with one of three Elsinoë species studied (Figure 6). All domestic E. australis suspects fell within the E. australis clade. Furthermore, these suspects are all members of an E. australis subclade comprised entirely of the Natsudaidai pathotype. A similar NJ analysis of the ITS region, minus $E$. veneta, resulted in two clades, each with compositions corresponding to E. australis and E. fawcettii (Figure 7). All E. australis domestic suspects are members of the E. australis clade. Within this E. australis clade, three domestic suspects are members of a subclade that contain all samples of the sweet orange pathotype, whereas the remaining occupy unresolved positions in the E. australis clade along with all Natsudaidai pathotype samples.
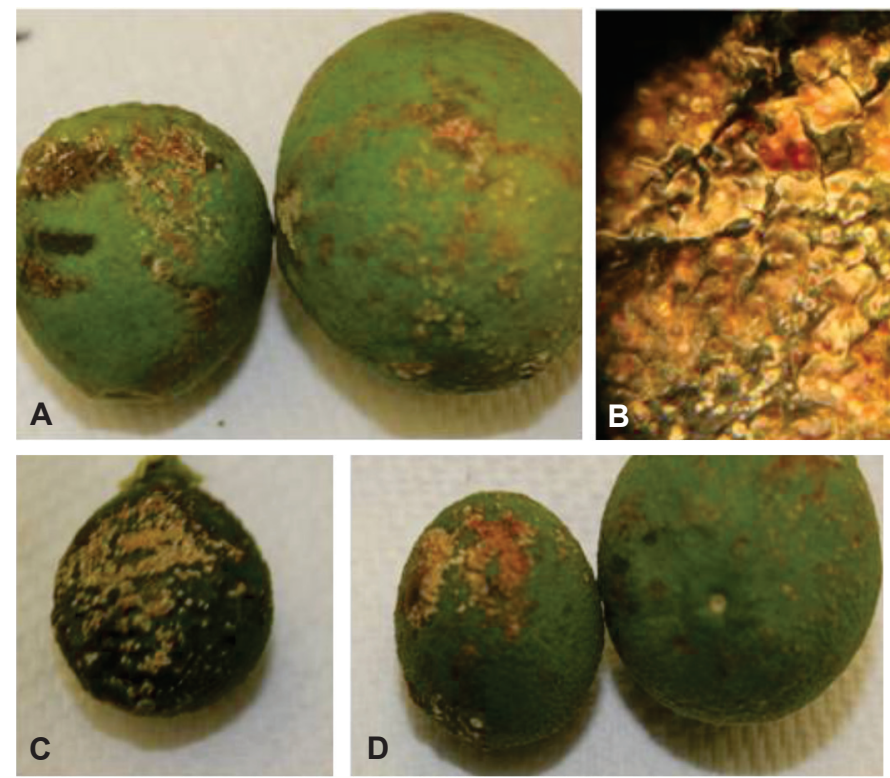
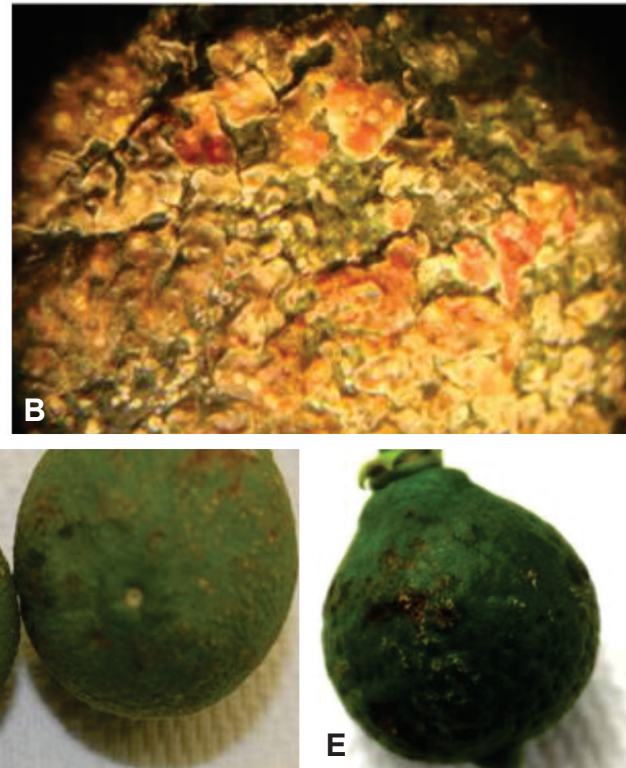

FIGURE 4 - Small immature citrus fruits developed scabby lesions 10 days after inoculation with conidial suspensions. A. grapefruit; B. a close-up of the grapefruit lesion; C. sweet orange and D. satsuma mandarin; E. satsuma mandarin.

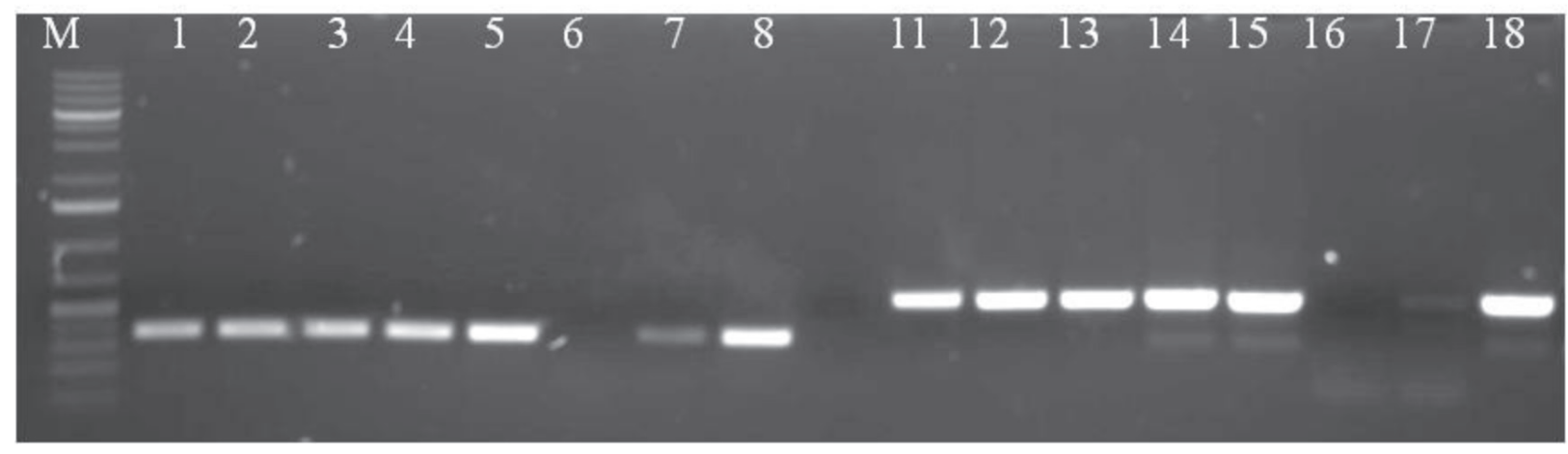

FIGURE 5 - PCR amplification products obtained from the sweet orange scab disease lesions associated with Elsinoë australis of the grapefruit and sweet orange collected in Lower Rio Grande Valley orchards using E. australis species-specific primers Eaut-5 and Natsudaidai pathotype-specific primer set Ea Nat 1. Lanes 1-4 (grapefruit) \& 5-8 (sweet orange): 363-bp PCR amplicons obtained using Eaut-5 and lanes 11-14 (grapefruit) \& 15-18 (sweet orange): 578-bp fragments obtained using Ea Nat 1 primer set. $\mathrm{M}=1 \mathrm{~Kb}$ DNA ladder (Fermentas). 


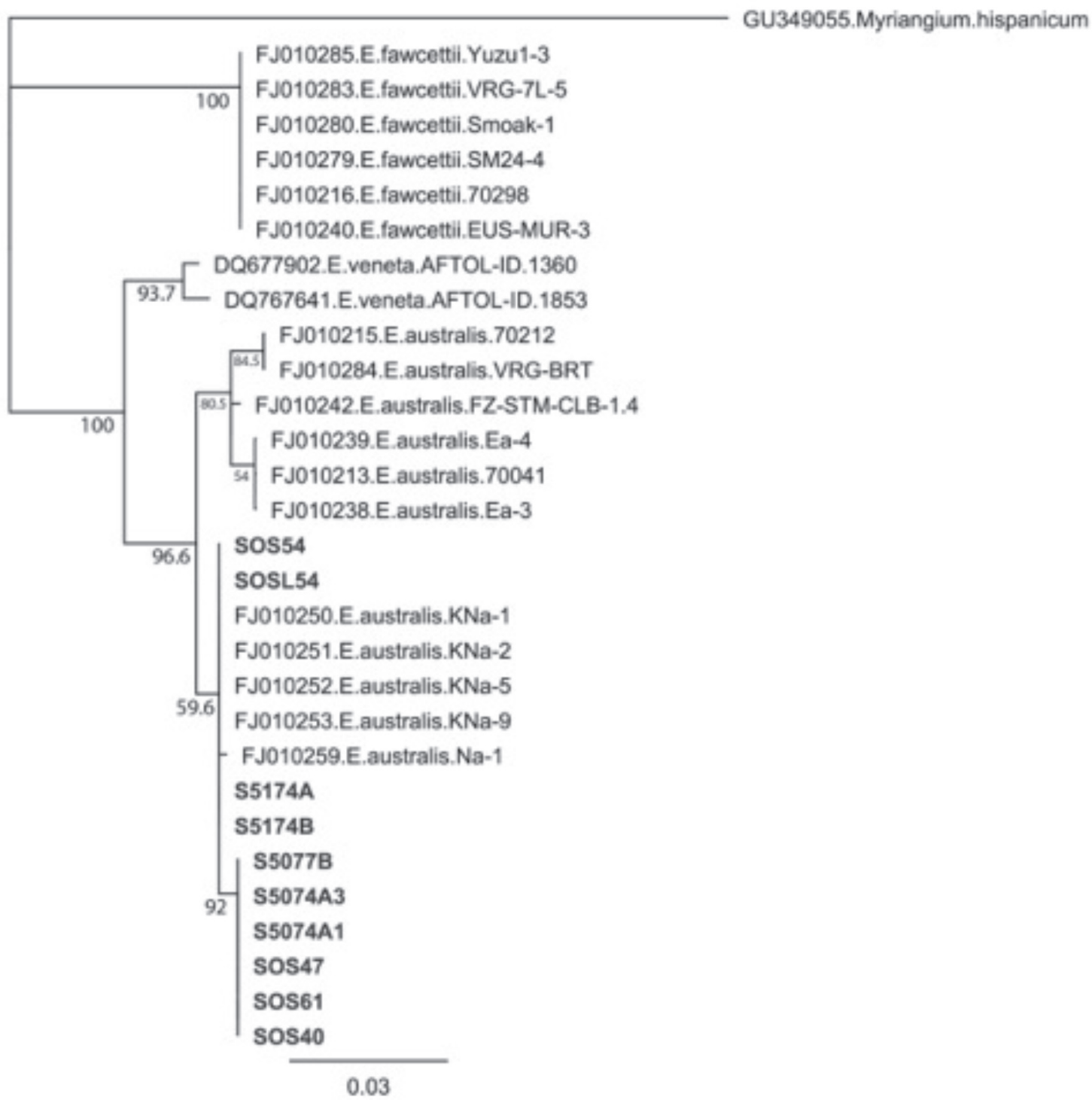

FIGURE 6 - Neighbor-joining consensus tree (1000 bootstrap replications) based on the alignment of partial elongation factor $1 \alpha$ (TEF) gene nucleotide sequences obtained for the Elsinoë australis isolates recovered by the authors (bold) and several other sequences from GenBank database that showed high similarity.

\section{DISCUSSION}

In this study, many fruit samples from different citrus species and a few leaf samples were positive for $E$. australis by PCR. We have successfully isolated $E$. australis from grapefruit, sweet orange, and mandarin fruit collected in Texas and confirmed the isolate identity by colony characteristics, conidial morphology, and PCR. Moreover, we were able to inoculate detached leaves of grapefruit, sweet orange, and lemon and detached fruit of grapefruit, lemon, and sweet orange under laboratory conditions and inoculated fruits and leaves showed scab symptoms. PCR assays using tissue collected from the infected lesions indicated presence of the fungus, and the identity of $E$. australis was further confirmed by re-isolation of the fungus from inoculated detached leaf and fruit on
Whiteside's semi-selective medium. Furthermore, PCR on the re-isolated fungal colonies confirmed the pathogen to be E. australis.

This study is the first report of E. australis in the USA. We found that in Texas it affects many species of citrus including lemon and grapefruit in addition to sweet orange and mandarins. The symptoms associated with the presence of the fungus vary widely; many are typical scab symptoms, but many would not have been diagnosed as scab even by professionals with considerable experience with the disease. The lack of a specific symptom associated with samples positive for PCR for E. australis has made diagnosis of the disease for regulatory purposes very difficult and determination of the presence of the pathogen has depended primarily on PCR using specific primers. We have determined that the E. australis isolates used in 


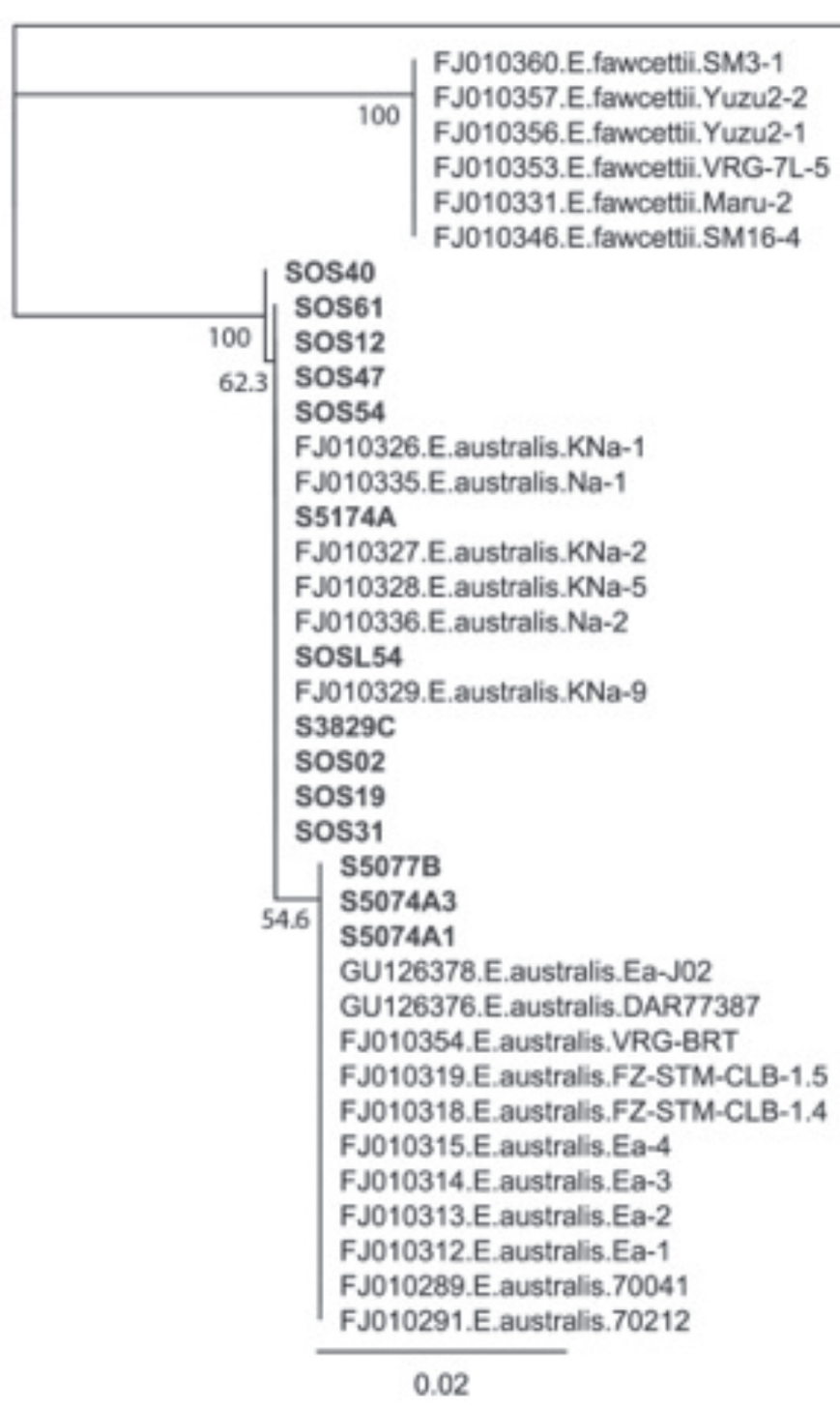

JF424297.Myriangium.clone.AC_0_B12

FJ010357.E.fawcettii.Yuzu2-2

FJ010356.E.fawcettii.Yuzu2-1

FJ010353.E.fawcettii.VRG-7L-5

FJ010331.E.fawcettii.Maru-2

$\operatorname{OS} 40$

Sos61

sos 47

SOS54

S5174A

F.J010327.E.australis.KNa-2

FJ010328.E.australis.KNa-5

E australis.Na-2

FJ010329.E.australis.KNa-9

S3829C

os 31

S5077B

S5074A1

GU126378.E. australis Ea-J02

GU126376.E.australis.DAR77387

FJ010354.E.australis.VRG-BRT

FJ010319.E australis.FZ-STM-CLB-1.5

FJ010318.E-australis.FZ-STM-CLB-1.4

FJ010315.E. australis. Ea-4

FJ010314.E australis. Ea-3

FJ010313.E. australis.Ea-2

FJ010312.E australis. Ea-1

FJ010289.E.australis. 70041

0.02

FIGURE 7 - Neighbor-joining consensus tree (1000 bootstrap replications) based on the alignment of internal transcribed spacer region (ITS) gene nucleotide sequences obtained for the Elsinoë australis isolates recovered by the authors (bold) and several other sequences from GenBank database that showed high similarity.

this study are pathogenic to fruit and leaves of many citrus species in laboratory tests; however, symptom expression under field conditions is unknown. It differs from sweet orange scab in South America in producing symptoms on leaves as well as on fruit although few symptomatic leaves were positive by PCR.

Molecular analysis indicates that all of the isolates recovered from the USA correspond closely with the Natsudaidai pathotype of E. australis from South Korea. There is no indication that the fungus was introduced from South America. Interestingly, the Natsudaidai pathotype of E. australis was also recently isolated and proven to cause a scab disease of jojoba in Australia (Ash et al., 2012). The isolates of E. australis from jojoba are apparently not pathogenic to citrus, as demonstrated by leaf and fruit inoculations. The origin of E. australis in the USA remains unknown, but this species may be much more widely distributed on other plant species and in other areas than was previously thought and may have been present for some time.

PCR-positive samples and some cultures have been obtained from semi-arid to arid citrus areas in Texas and Arizona. This is surprising since scab is primarily a disease problem on citrus in humid areas (Whiteside, 1975) and normally would not be expected to occur, much less, cause significant disease on citrus in those areas. Citrus scab in Florida does not spread readily from tree-to-tree (Timmer, personal observations). Most of the spread occurs on nursery trees which are grown in high densities with overhead irrigation where the opportunity for spread 
is very high. Conidia of Elsinoe spp. are very fragile and desiccate quickly. However, they do germinate and infect plants in 2-3 h (Agostini et al., 2003; Whiteside, 1975). It is possible that these fungi are really adapted to areas of high dew and little rain. They may have some means of survival on mature leaves and other organs which allows them to withstand long periods in the absence of moisture. This may explain a conundrum with sweet orange scab in South America. There, the disease affects only fruit with no apparent infection on leaves. It has always been a puzzle as to where the inoculum comes from for the next crop if the previous crop has already been harvested. The pathogen may survive as an epiphyte or endophyte in wounded citrus leaves or other organs.

As pointed out above, several symptoms are associated with the presence of E. australis on citrus fruit and leaves. The most common site for the fungus are wounds resulting from "late-season windscar". That symptom may be produced by the fungus or it may be residing there as an epiphyte or endophyte. PCR of normal healthy looking fruit rind or fruit with rust mite (Phyllocoptruta oleivora) damage or other smooth, superficial blemishes are rarely positive. Thus all of the symptoms associated with the presence of the fungus are deep wounds in fruit or leaves. Such tissues are sufficiently rough in texture to perhaps help retain the moisture on those surfaces longer than on smooth surfaces and this may favor growth of the pathogen.

\section{ACKNOWLEDGEMENTS}

The authors sincerely thank Dr. S. Mondal, in the laboratory of Dr. Megan M. Dewdney of the Citrus Research \& Education Center, University of Florida, Lake Alfred, Florida, for providing technical assistance in Elsinö̈ fawcettii fungal isolation techniques, inoculations, and pathogenicity tests. The work reported here was partially funded by USDA-APHIS-PPQ and the Texas Citrus Producers Board.

This material was made possible, in part, by a Cooperative Agreement from the United States Department of Agriculture's Animal and Plant Health Inspection Service (APHIS). It may not necessarily express APHIS' views.

\section{REFERENCES}

Agostini JP, Bushong PM, Bhatia A, Timmer LW (2003) Influence of environmental factors on severity of citrus scab and melanose. Plant Disease 87:1102-1106.

Ash GJ, Stodart B, Graham EH, Hyun JW (2012) Black Scab of jojoba (Simmondsia chinensis) in Australia caused by a putative new pathotype of Elsinoë australis. Plant Disease 96:629-634.

Bitancourt AA, Jenkins AE (1937) Sweet orange scab caused by
Elsinoë australis. Journal of Agricultural Research 54:1-18.

CABI (2010) Elsinoë australis. Crop Protection Compendium report - Elsinoë australis (citrus scab). Available at: www.cabi. org $/$ isc $/$ ?compid $=5 \&$ dsid $=20774 \&$ loadmodule $=$ datasheet $\&$ page $=$ 481\&site $=144$. Accessed on September $25^{\text {th }}, 2012$.

Chung KR (2010) Elsinoë fawcettii and Elsinoë australis: the fungal pathogens causing citrus scab. Molecular Plant Pathology 12:123-135.

Dams E, Hendriks L, Van de Peer Y, Neefs JM, Smits G, Vandenbempt I, De Wachter R (1988) Compilation of small ribosomal subunit RNA sequences. Nucleic Acids Research 16:87-173.

Drummond AJ, Ashton B, Buxton S, Cheung M, Cooper A, Heled J, Kearse M, Moir R, Stones-Havas S, Sturrock S, Thierer T, Wilson A (2011) Geneious Pro 5.4.4 software, Available at: www. geneious.com. Accessed on September 25 th 2012.

Glass NL, Donaldson GC (1995) Development of primer sets designed for use with the PCR to amplify conserved genes from filamentous ascomycetes. Applied and Environmental Microbiology 61:1323-1330.

Hyun JW, Peres NA, Yi SY, Timmer LW, Kim KS, Kwon HM, Lim HC (2007) Development of PCR assays for the identification of species and pathotypes of Elsinoë causing scab on citrus. Plant Disease 91:865-870.

Hyun JW, Timmer LW, Lee SC, Yun SH, Ko SW, Kim KS (2001) Pathological characterization and molecular analysis of Elsinoë isolates causing scab diseases of citrus in Jeju Island in Korea. Plant Disease 85:1013-1017.

Hyun JW, Yi SH, MacKenzie SJ, Timmer LW, Kim KS, Kang SK, Kwon HM, Lim HC (2009) Pathotypes and genetic relationship of worldwide collections of Elsinöe spp. causing scab diseases of citrus. Phytopathology 99:721-728.

Jenkins AE (1933) A Sphaceloma attacking Navel orange from Brazil. Phytopathology 23:538-545.

Timmer LW (1974) An outbreak of sour orange scab in Texas. Journal of the Rio Grande Valley Horticultural Society 28:137139.

Timmer LW, Priest M, Broadbent P, Tan MK (1996) Morphological and pathological characterization of species of Elsinoë causing scab diseases of citrus. Phytopathology 86:1032-1038.

Timmer LW (2000) Scab diseases. In: Timmer LW, Garnsey SM, Graham JH (Eds.) Compendium of Citrus Diseases. St. Paul MN, USA. APS Press. pp. 31-32.

Vilgalys R, Hester M (1990) Rapid genetic identification and mapping of enzymatically amplified ribosomal DNA from several Cryptococcus species. Journal of Bacteriology 172:4238-4246.

Whiteside JO (1986) Semiselective media for the isolation of Elsinoë fawcettii from citrus scab pustules. Plant Disease 70:204206.

Whiteside JO (1975) Biological characteristics of Elsinoë fawcettii pertaining to the epidemiology of sour orange scab. Phytopathology 65:1170-1177. 